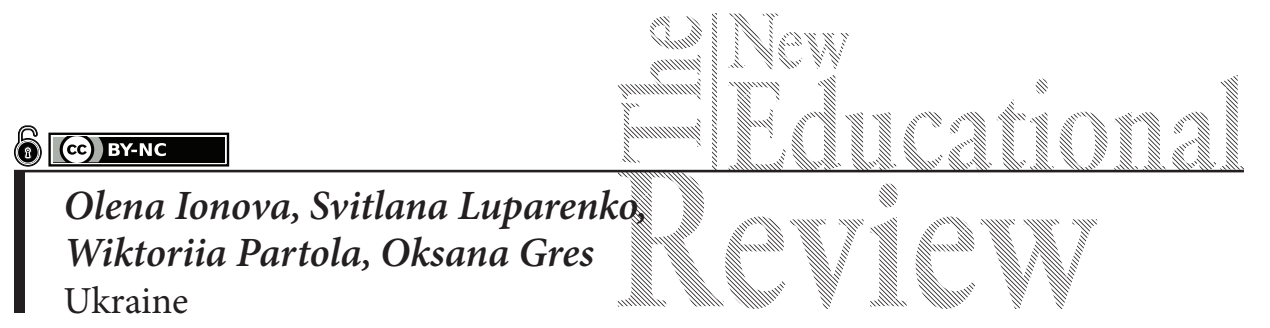

\title{
Waldorf Approaches to Organization of the Pedagogical Process and Their Influence on the Quality of Education of Ukrainian Junior Schoolchildren
}

DOI: 10.15804/tner.2018.54.4.11

\begin{abstract}
With the aim of determination of the influence of Waldorf approaches to the organization of the pedagogical process on the quality of education of Ukrainian junior schoolchildren, the presented experimental research was carried out over the period 2014-2016. Third grade schoolchildren of general educational institutions were involved in the experimental research. The organizational forms and methods of Waldorf school were implemented. They were: rhythmic organization of the pedagogical process, artistic teaching, limited use of standard textbooks and schoolchildren's work on drawing up their own work notebooks, involvement of art elements in the study of all subjects, differentiated exercises for children with different types of temperament, use of active-practical projects, active exercises and games. The positive influence of Waldorf approaches on the quality of schoolchildren's knowledge (fullness of knowledge and level of their assimilation) and development of their personal-motivational sphere (junior schoolchildren's attitude to learning, levels of their cognitive activity) was detected. An increase in the level of schoolchildren's activity and autonomy in educational-cognitive activity was found. The obtained data makes it possible to disseminate Waldorf educational experience for improving the quality of education of junior schoolchildren.
\end{abstract}

Keywords: junior schoolchildren, pedagogical process, organization, quality of education, Waldorf approaches 


\section{Introduction}

One of the priority tasks of modern school is education of comprehensively developed personality, which is characterized by flexibility of thinking, autonomy, initiative and ability to work and learn throughout life. Primary school, which lays the foundation for further education and human development, is extremely important for the formation of such personal qualities. However, it requires special organization of the educational process of the primary level of education, and this organization should be aimed at the development of the above-mentioned qualities.

In this context, the study and use of the achievements of Waldorf pedagogy, which is nearly 100 years old (the first Waldorf school was founded in Stuttgart, Germany, in 1919), are of particular value. For this period, it has strengthened its position and become a wide international educational and cultural movement that covers more than 60 countries on all the continents of the world, having different cultural-historical and religious traditions and political systems.

World experience shows that the construction of the Waldorf pedagogical process allows for bringing up a personality with individual understanding, independent and acting responsibly, with developed culture of cognitive activity, mathematical and natural, research and creative abilities. This is confirmed by the data of international independent comparative pedagogical research into the quality of pupils' academic achievements, in particular TIMSS (quality of natural and mathematical education) and PISA (quality of information perception, reading, understanding of texts).

Quite a high percentage of graduates of Waldorf schools, where there is no selection of pupils by intellectual and other indicators, successfully pass abitur (state exams which give the right to enter a higher school). In particular, the number of graduates who pass that exam is $20-30 \%$ higher in Waldorf schools than the national average. Most of the former Waldorf pupils are highly competitive in the labor market, successfully make a professional choice and they are satisfied with their professional activity. That is why there are almost no unemployed people among them.

The governments of the countries where Waldorf schools have a long history and strong roots (Germany, Scandinavian countries) support them economically, believing pragmatically that thereby they save a lot of money on conducting reform experiments, as Waldorf schools are the best sources of ideas and examples of innovations.

A striking example is the Finnish education system, which is considered to be the most efficient in the world. It took a lot from Waldorf school in the conceptual 
and technological aspects, in particular: education according to age and creative-artistic methods of education, principle of verbal evaluation, use of elements of games and discoveries at primary school, learning two foreign languages from the first grade, one class teacher in the basic school, etc.

Analysis of recent research and publications proves that the philosophical, psychological-pedagogical bases of Waldorf pedagogy were substantiated, first of all, in the scientific heritage of the founder of Waldorf school, Rudolf Steiner (1861-1925), a famous European thinker, scientist, pedagogue (Steiner, 1984, 1990, 1992). The theoretical foundations of Waldorf pedagogy were also revealed by modern scientists, in particular H. Bartz \& D. Randoll (Bartz, \& Randoll, 2007), L. Gessler (Gessler, 1988), E. Kranich (Kranich, 1999), T. Marti (Marti, 2005) and others.

At the same time, some publications reveal superficial and even distorted ideas about Waldorf pedagogy. Some people express unwarranted thoughts about Waldorf school as "art school" or "labour school", and they consider Waldorf school to be most suitable for disabled children. Other people think that Waldorf schools "have a good atmosphere but they do not teach children properly", i.e., Waldorf school gives secondary attention to the acquisition of knowledge and skills by pupils. And finally, some people believe that specific Waldorf practices lead to formation of schoolchildren's sense of their own exclusivity and emergence of certain child complexes, situational and personal anxiety.

Thus, the problem of Waldorf approaches to the organization of the pedagogical process and their influence on the quality of education of Ukrainian schoolchildren has not been under careful consideration before and remains unsolved.

The aim of the article is to determine the impact of Waldorf approaches to the organization of the pedagogical process on the quality of education of Ukrainian junior schoolchildren.

\section{Research Methodology}

A complex pedagogical experiment, which was carried out in ascertaining, forming and control stages in 2014-2016, was the leading method of research. According to the program of the experiment, there were two groups: an experimental group (E) (152 people) and a control group (C) (154 people). These groups included third grade schoolchildren from the state secondary schools in the Kyiv, Kharkiv and Kharkiv regions. The schoolchildren of the experimental group were taught with the use of Waldorf methods, and the schoolchildren of the control group were taught with the use of traditional methods. 
Besides, such research methods as observation, individual and group talks, oral questioning, control work, current assessment, final test, questionnaire, etc., were used during the experiment for determining the levels of formation of different indicators of the quality of educational content assimilation by the primary school pupils.

The method of mathematical statistics ( $c^{2}$ criterion) was used to compare the results obtained at the ascertaining and control stages of the experiment, to determine the statistical significance of the influence of Waldorf approaches to the organization of the pedagogical process on the quality of the education of schoolchildren.

\section{Research Results}

The main Waldorf approaches to the education of junior schoolchildren were introduced in the experimental work. They were adapted to the conditions of Ukrainian primary school and included rhythmic organization of the pedagogical process, artistic teaching, limited use of standard textbooks and pupils' work on drawing up their own work notebooks, involvement of art elements in the study of all disciplines, active exercises and games, use of active-practical individual and group projects, differentiated exercises for children with different types of temperament.

The rhythmic organization of the pedagogical process is based on natural rhythms of variation of human consciousness and an ability to concentrate. It provides a uniform load for the child's intellectual and emotional-volitional sphere, prevents fatigue, maintains and increases children's physical and mental-spiritual forces and thus promotes the growth of a person's cognitive interest. Rhythmization of education requires compliance with the following rhythms: year rhythm, week and day rhythms, and rhythm of a lesson. Year rhythm is provided by curriculum and training programs and realized through learning by the "epoch" method, i.e., training cycles lasting 3-4 weeks, during which pupils are taught the subjects of the cognitive cycle (native language, mathematics, nature study, etc.). Week and day rhythms are determined by timetable and mean conducting "the main lesson" in a cognitive subject at the beginning of a school day, which requires children's deep comprehension, understanding of information and intellectual work. After "the main lesson" pupils learn subjects which need constant rhythmic repetition (foreign languages, subjects of the aesthetic cycle). The subjects of practical orientation (crafts, artistic work, etc.) are taught at the end of a school day. The rhythm 
of a lesson is provided by three parts of a lesson (rhythmic, main and final parts) and constant change of activities.

Artistic teaching is aimed at junior schoolchildren's activation through the development of aesthetic feelings in the learning process. It included imaginative presentation of the learning material by the teacher, which meant creation and representation of knowledge in the form of vivid artistic images that caused pupils' certain internal attitude (gladness and sadness, surprise and irony, admiration and irritation, empathy and estrangement, etc.)

Limited use of a standard textbooks and pupils' work on drawing up their own work notebooks ("epoch" copybooks) included processing of different sources (reading books, reference books, collections of tasks, etc.), their summarizing and note-taking (with the teacher's help or without it) and appropriate self-illustration of "epoch" copybooks (figures, tables, pictures, schemes, plans, etc.).

The involvement of art elements in the study of all disciplines involved exercises with colours and shapes, playing musical instruments, modeling, poetry, eurythmy, art of movement, theatrical art, etc. Art elements made it possible to establish an active correlation of knowledge and action, due to which aspiration to cognition was permeated with love for it, and in the learning process a child could act as an artist or as a spectator who experiences a work of art and reproduces it through this experience.

Active exercises and games included playing fingers games on lessons, children's work on school grounds or in a workshop (work with paper, cardboard, cloth, natural materials, manufacture of products from different materials, needlework and crafts, household work, etc.), playing and experiencing different game situations, into which a child can get in his/her real life (school or family).

The use of active-practical individual and group projects meant the pupils' implementation of various projects in different subjects and interdisciplinary projects ("Building a house", “Growing bread", "My family", "My school”, "My friends", "Environment”, "Folk festivals", "Tales and legends", annual theatrical performances, etc.). This work directed the schoolchildren to carrying out certain investigations, and their results were presented to the whole class and accompanied by demonstration of illustrative and demonstrative material made by the children (small items, pictures, musical works, postcards, calendars, cards, newspapers, etc.).

Differentiated exercises for the children with different types of temperament were focused on satisfaction of the children's personal interests and needs, harmonization of their mental life, organization of a learning process for every child in a way which is appropriate for them. It was realized through the teacher's use of different techniques of telling and explaining, which aroused feelings and emotions 
specific for each child (drama for choleric, empathy for melancholic, slowness and imagery for phlegmatic, liveliness for sanguine), doing differentiated tasks by the schoolchildren, which helped to reduce the negative sides of their temperament, reveal emotions and feelings adequately and increase their interest in learning.

Based on the analysis of psychological-pedagogical sources, observations of the schoolchildren's educational activities and expert assessments, the main criteria and indicators of qualitative assimilation of the content of education by the junior pupils were determined. They were the fullness of subject knowledge and the level of its assimilation.

The experimental results of the assimilation of subject knowledge by the junior schoolchildren were obtained after mathematical processing and presented in Table 1.

Table 1. Formation of junior schoolchildren's quality of knowledge (percentage increase)

\begin{tabular}{|c|c|c|c|c|c|c|}
\hline \multirow{4}{*}{ Criteria and Indicators } & \multicolumn{6}{|c|}{ Subjects } \\
\hline & \multicolumn{2}{|c|}{ Mathematics } & \multicolumn{2}{|c|}{ Native Language } & \multicolumn{2}{|c|}{ Nature Study } \\
\hline & \multicolumn{6}{|c|}{ Group of schoolchildren (number of people) } \\
\hline & $\begin{array}{c}\mathrm{E} \\
(152)\end{array}$ & $\begin{array}{c}\mathrm{C} \\
(154)\end{array}$ & $\begin{array}{c}E \\
(152)\end{array}$ & $\begin{array}{c}C \\
(154)\end{array}$ & $\begin{array}{c}\mathrm{E} \\
(152)\end{array}$ & $\begin{array}{c}\mathrm{C} \\
(154)\end{array}$ \\
\hline Fullness of knowledge & 12.5 & 5.2 & 7.8 & 6.7 & 9.2 & 4.8 \\
\hline $\begin{array}{l}\text { The level of knowledge quisition: } \\
\text { - stable (a pupil has a strong and deep } \\
\text { subject knowledge, uses knowledge } \\
\text { in new situations); }\end{array}$ & 9.9 & 3.9 & 4.6 & 3.2 & 7.2 & 4.6 \\
\hline $\begin{array}{l}\text { - situational (a pupil knows the learn- } \\
\text { ing material fairly well and uses } \\
\text { knowledge in standard situations); } \\
\text { - low (a pupil has a superficial and } \\
\text { limited subject knowledge, does } \\
\text { tasks on the model) }\end{array}$ & -30.3 & -15.6 & -29.6 & -20.1 & -29.6 & -20.8 \\
\hline
\end{tabular}

Analysis of the obtained results allows for drawing a conclusion about the effectiveness of the work on the acquisition of subject knowledge by the schoolchildren. For example, we observed a significantly greater increase in the fullness of knowledge (in all the core subjects - mathematics, native language (Ukrainian or Russian) and nature study) in the experimental group than in the control group.

The comparison of the results of the schoolchildren's knowledge acquisition while studying cognitive subjects indicates that this process was the most effective 
in mathematics and less effective while studying native language (nature study took an intermediate position).

Thus, the Waldorf methods of teaching mathematics let the children perceive numbers and operations on them by all the senses (hearing, vision, sense of smell, touch, etc.), feel and experience them due to the sense of rhythm, movement and balance. That is why the Waldorf methods are effective means of awakening the child's intellect through active emotional-volitional activity and qualitative knowledge acquisition by most children.

The obtained data is also confirmed by studies of the effectiveness of mathematical education of junior pupils at Waldorf School of Free Development, Kharkiv. This research was carried out under International Comparative Project on Mathematical Attainment (IPMA) at the initiative of Exeter University, Great Britain. Based on long-term (for three years) monitoring of mathematics learning process by a group of independent experts, the success of Waldorf pupils' mathematical education (mastery of mathematical abilities, understanding of mathematical knowledge and skills, ability to use them creatively) was confirmed. The children also showed well-developed verbal-logic and spatial thinking. However, the process of learning native language had a particularly beneficial effect on those pupils who had difficulties in it.

The results of the experimental work on Waldorf approaches to the organization of the educational process and their impact on the development of the junior schoolchildren's personal-motivational sphere are presented in Table 2.

Table 2. The development of junior schoolchildren's personal-motivational sphere (percentage increase)

\begin{tabular}{|c|c|c|}
\hline \multirow[b]{2}{*}{ Criteria and Indicators } & \multicolumn{2}{|c|}{ Groups } \\
\hline & $\begin{array}{c}E \\
(152)\end{array}$ & $\begin{array}{c}\mathrm{C} \\
(154)\end{array}$ \\
\hline \multicolumn{3}{|l|}{ Junior schoolchildren's attitude to learning: } \\
\hline $\begin{array}{l}\text { - positive-active (pupil likes going to school, learns with pleasure, has a positive } \\
\text { informal attitude to school and teachers, realizes the importance of gaining } \\
\text { knowledge, strives to achieve success in education); }\end{array}$ & 19.7 & 7.1 \\
\hline $\begin{array}{l}\text { - positive-indifferent (pupil wants to learn, but he/she does not always make ef- } \\
\text { forts to succeed in education and does not realize the importance of gaining } \\
\text { knowledge completely); }\end{array}$ & -17.1 & -4.5 \\
\hline $\begin{array}{l}\text { - negative (pupil does not realize the importance of gaining knowledge, has } \\
\text { explicit or implicit unwillingness to learn and a passive attitude to success in } \\
\text { education). }\end{array}$ & -2.6 & -2.6 \\
\hline
\end{tabular}




\begin{tabular}{|c|c|c|}
\hline \multirow[b]{2}{*}{ Criteria and Indicators } & \multicolumn{2}{|c|}{ Groups } \\
\hline & $\begin{array}{c}\mathrm{E} \\
(152)\end{array}$ & $\begin{array}{c}\mathrm{C} \\
(154)\end{array}$ \\
\hline \multicolumn{3}{|l|}{ The levels of cognitive interest: } \\
\hline $\begin{array}{l}\text { - stable (pupil is eager to learn, asks many questions, has a desire to learn new } \\
\text { material, does tasks with interest and without the teacher's help, does not } \\
\text { need additional external incentives for knowledge acquisition); }\end{array}$ & 9.2 & 3.9 \\
\hline $\begin{array}{l}\text { - situational (pupil has episodic interest in education as a response to some } \\
\text { emotionally colored situation, needs external support for acquiring new } \\
\text { knowledge and autonomous work); }\end{array}$ & -7.2 & -7.8 \\
\hline $\begin{array}{l}\text { - disinterest (pupil is not interested in the learning process and needs constant } \\
\text { external stimulation for activation and autonomy in learning) }\end{array}$ & -2.0 & -3.9 \\
\hline
\end{tabular}

The analysis of the data helps to conclude that the Waldorf approaches had a positive influence on the dynamics of the junior schoolchildren's attitudes to learning and their levels of cognitive interest.

The above-mentioned changes occurred due to the orientation of the Waldorf approaches to the child's personality, the teacher's respectable and attentive attitude to the child with reasonable requirements, which awakens interest in learning, forms intrinsic motivation for educational-cognitive activity (desire to learn).

According to our observations, the use of the Waldorf approaches also contributed to the formation of the pupils' communicative skills and abilities (abilities to listen and understand an interlocutor, express ideas on the topic of conversation, conduct a monologue and dialogue) and led to positive changes in the nature of the schoolchildren's relations. It was facilitated by creation of a favorable psycho-emotional background of the educational process, atmosphere of mutual trust and emotional emancipation.

\section{Discussion}

On the whole, the obtained data allows for concluding that realization of the Waldorf approaches positively influenced the assimilation of educational content by the schoolchildren. This is due to the fact that the Waldorf pedagogical process creates favorable prerequisites for assimilation of educational content by the child while promoting his/her holistic development (intellectual-cognitive, emotional-value, moral-volitional, personal-social).

For example, the rhythmic organization of the pedagogical process, learning with the use of the "epoch" method in particular, stimulated the children's cognitive 
activity, organized systematical and deepened processing of the educational material, provided personally significant and strong mastery of knowledge, facilitated mobile transfer of the acquired skills within a particular topic or subject area.

Artistic teaching in the conditions of limited use of standard textbooks and creation of their own textbooks ("epoch" copybooks) by the schoolchildren enriched their emotional perception, stimulated initiative and interest in learning, encouraged understanding and self-reflection of educational information, memorization of knowledge and its active use.

Active-practical projects promoted the development of individual activity and personal autonomy, enabled the widespread application of knowledge and experience in different subjects, generalization and consolidation of the acquired skills, creative use of them in new or changeable conditions.

Differentiated exercises for the children with different types of temperament, due to their focus on the peculiarities of the psychological structure of personality, significantly contributed to individualization of the educational process, stimulated the development of the schoolchildren's cognitive interest, initiative and learning autonomy.

Different types of work aimed at activation of the children's perception, development of their sensory and fine motor skills (finger games, various manual labor) and art elements organically alternated with other kinds of activity in the process of study of all subjects promoted effective assimilation of the educational content by the schoolchildren.

Informal inclusion of artistic, poetic and musical perception of the world caused certain feelings in the children's soul. On the one hand, children began to treat color and sound variety more emotionally, and on the other hand, they began to understand and feel deeper the true and false, beautiful and ugly, moral and immoral in the world.

For instance, introduction of art elements (recitation, drawing forms, a system of exercises with liquid paints) in learning native language helped to develop the children's active perception and ideas, their mobile volitional actions, which is very important for the formation of a sense of language, development of an ability to understand the meaning of what they heard and read.

The combination of music and learning mathematics, work with musical-rhythmic patterns, differentiation of sounds (by frequency, rhythm, tempo) helped to learn verbal counting or fractions better.

Learning nature study accompanied by art and plastic activities (modeling with wax, clay, plasticine) helped to form the pupils' holistic, ecologically oriented ideas of nature. 
Thus, generalization of the conducted analysis makes it possible to assert that some researchers' ideas about Waldorf school as en educational establishment that does not pay enough attention to schoolchildren's qualitative assimilation of the educational content were not confirmed. The conducted analysis also allows for asserting that the statement about the negative influence of Waldorf school on the child's development is not true.

The conducted study does not cover all the aspects of the problem. The perspective directions of further research can be the following: analysis of the influence of Waldorf approaches on the quality of education of middle and high school pupils, study of the problem of teacher training concerning the introduction of Waldorf approaches into the organization of the pedagogical process.

\section{Conclusions}

The relevance of the study is caused by the need to improve the quality of junior schoolchildren's education and the opportunity to attract Waldorf educational experience to solve the above-mentioned problem.

The positive influence of Waldorf organizational forms and methods on the quality of education of junior schoolchildren was experimentally proved. The research found an increase in the quality of the schoolchildren's knowledge, the level of their activeness and autonomy in learning-cognitive activity. The process of knowledge acquisition was the most efficient in studying mathematics, slightly less effective while learning nature study and native language. It was noted that the Waldorf approaches had a particularly favorable impact on the schoolchildren who had difficulties in learning native language.

Positive changes in the children's personal-motivational sphere, their mainly positive-active attitude to learning and stable level of cognitive interest were found. It was found that the Waldorf approaches had a positive influence on the schoolchildren who had indifferent and negative attitudes to education. Positive changes in the formation of the schoolchildren's communicative skills and relationships with each other and teachers were also found 


\section{References}

Barz, H., \& Randoll, D. (2007). Absolventen von Waldorfschulen. Eine empirische Studie $z u$ Bildung und Lebensgestaltung [Graduates of Waldorf schools. An emperical study of education and lifestyle]. Wiesbaden: VS Verlag für Sozialwissenschaften.

Gessler, L. (1988). Bildungserfolg im Spiegel von Bildungsbiographien [Educational success in educational biographies]. Frankfurt am Main; Bern; New York; Paris.

Kranich, E.M. (1999). Anthropologische Grundlagen der Waldorfpädagogik [Anthropological bases of Waldorf pedagogy]. Stuttgart: Verlag Freies Geistesleben.

Marti, T. (2005). Wie kann schule die Gesundheit fördern? Erziehungskunst und Salutogenese [How can school promote good health? Educational art and salutogenesis]. Stuttgart:Verlag Freies Geistesleben.

Steiner, R. (1992). Allgemeine Menschenkunde als Grundlage der Pädagogik [General study of man as a basis of Pedagogy]. Dornach/Schweiz: Rudolf Steiner Verlag.

Steiner, R. (1990). Erziehungskunst. Methodisch-Didaktisches [The art of education. Methodology and Didactics]. Dornach/Schweiz: Rudolf Steiner Verlag.

Steiner, R. (1984). Erziehungskunst. Seminarbesprechungen und Lehrplanvorträge [The art of education. Seminar discussions and lectures about curriculum]. Dornach/Schweiz: Rudolf Steiner Verlag.

Advised by Professor Svitlana Zolotukhina, Kharkiv H.S. Skovoroda National Pedagogical University, Kharkiv, Ukraine 